氏名 (本籍) 川村啓造 (福泪)

学位 の種 類 学位記番号 学位授与日付 学位授与の要件 学位論文題目 論文審査委員
粜学博士

\section{乙 第118号}

昭和52年 9 月 30 日

博士の学位論文提出者（学位規則第 5 条第 2 項該当者）

ヒト口蓋腺の oncocyte 出現に関する病理組織学的研究

$\begin{array}{cccccc}\text { (主 查) 教授 } & \text { 上 } & \text { 野 } & \text { 正康 } \\ \text { (副) 查) 教授 } & \text { 山 } & \text { 田 } & \text { 博 } \\ \text { " } & \text { " 島 村 昭 辰 }\end{array}$

\title{
主論文の要旨
}

涶液腺腫瘍の組織発生と密接な関連が考えられる化生性変化の一つであり，またある種の唾液腺腫演の増殖上皮成

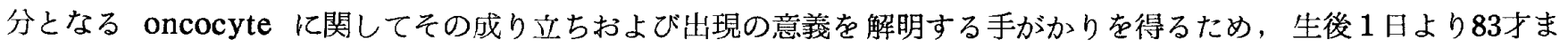
での剖検例 164 例から得られた口蓋腺における oncocyte の出現様式および出現状態を組織学的に検討した。

1. oncocyte は検索例中 143 例 $(87.2 \%)$ にみられ，生後 2 力月ですでに出現し，30才代以上では高頻度であ り, 出現程度の高い例は 50 才代以上に多くみられた。女性に比し男性にやや高頻度にみられた。

2. 口蓋腺の構成部位別の出現頻度では小葉内大導管および小葉間導管の中型導管で最も高く, 次いで小型導管, 腺房部で，排泄管では最も低かった。 oncocyte の部位的拡がりは中型導管を中心に加令とともに拡がりの大き い例が増加する傾向であった。

3. 導管壁での oncocyte 出現は孤在性から 全周性あるいは 1 層性から 重渞性のものなど種々の像がみられた が，導管壁を占める割合の多いものに2 層, 重層性のものが多く，50才代以上でその傾向がより著明であった。

4. oncocyte は同一例で多発性に出現するととが多く, また増殖傾问と考えられる種々の像が oncocyte 出現 例 143 例中 67 例 (46.9\%) にみられ，乙とに高年者に多かった。同一例でこれらの像のいくつか，または複数 個の同様な像がみられることもしばしばであった。

5. oncocyte の出現と口蓋腺の腺組織の萎縮,再生 および炎症などとの関連性は明らかでなかった.

6. 以上, oncocyte の出現には加令的因子の関与が推定され,ことに oncocyte の量的増加のみならず,部位的拨 がりおよび増殖傾向像の出現には加令との関連性がより強く認められた． 口蓋腺の一般的組織変化と oncocyte 出現との間に重視し得るものが見出されなかったことから， oncocyte の出現には局所的因子よりもむしろ何ら かの全身的因子の関与を推定することも否定できないと考えられた。

\section{論文番查の結果の要旨}

著者は oncocyte の成り立ちおよび腫焬発生との関連から， oncocyte 出現の意義を検討するため，七ト口蓋腺 164例（男性95例，女性69例）における oncocyte の出現様式およびその出現状態を組織学的に検討した結果，次の 様に結論している。

oncocyte の出現には，加令的因子の関与が推定され，ことに oncocyte の量的增加のみならず，部位的拡がりお よび多様な増殖像には加令との関連性がより強く認められる傾向が伺われたと述べている. 口蓋腺の一般的組織変化 と oncocyte 出現との間に重視し得るものが見出されなかったてとから, oncocyteのこうした出現には局所的因子 よりもむしろ何らかの全身的な风子の 関与を推定するてとも否定できないと考えられると言っている。そして，今 後, 他睡液腺についても同一症例で oncocyte の出現状態を検索すると共に他の化生性変化をも合わせ検討するこ とが必要であると結論している.

以上，本論文は唾液腺の oncocyte に関して種々なる新しい知見を得ており，この種の研究に資すること大なる ものがあり，学位論文として価値ある業績と判定した。 